\title{
Analisis Usahatani Cabai di Luar Musim Berdasarkan Penerapan Komponen Budidaya Cabai Merah di Provinsi Sulawesi Barat
}

\author{
Analysis of Chili Farming Business Outside of Season Based on the Application of Technology \\ in West Sulawesi Province
}

Nurhafsah, Rahmi H., Ida Andriani, Fitriawaty

Balai Pengkajian Teknologi Pertanian Sulawesi Barat

Kompleks Perkantoran Pemerintah Prov. Sulawesi Barat

Jl. H. Abdul Malik Pattana Endeng Mamuju-91512

E-Mail: nurhafsah_tiro@yahoo.com

Diterima: 10 Februari 2021; Disetujui: 30 Juni 2021

\begin{abstract}
ABSTRAK
Cabai merah merupakan salah satu komoditas sayuran unggulan yang mempunyai peranan strategis dalam struktur pembangunan perekonomian nasional. Harga cabai dipasaran cukup fluktuatif yang disebabkan oleh rendahnya produktivitas cabai yang dapat disebabkan oleh salah satu faktor seperti kurangnya penerapan teknologi budidaya cabai. Penelitian ini bertujuan untuk mengetahui pengaruh introduksi teknologi (penggunaan mulsa hitam perak, tanaman boorder, dan penggunaan jarak tanam) yang diberikan kepada petani terkait dengan peningkatan produktivitas budidaya cabai yang berdampak pada pendapatan petani. Penelitian ini dilaksanakan di Kabupaten Majene Provinsi Sulawesi Barat pada agroekosistem lahan kering dengan pendekatan penelitian adaptif. Data yang digunakan adalah data primer dan data sekunder. Hasil penelitian menunjukkan bahwa budidaya tanaman cabai dengan introduksi teknologi memberikan dampak yang lebih baik, baik dari tingkat produksi, dan menekan serangan hama dan penyakit berdasarkan pernyataan petani. Hasil analisis kelayakan usaha menunjukkan bahwa $\mathrm{B} / \mathrm{C}$ ratio dan $\mathrm{R} / \mathrm{C}$ ratio berdasarkan cara petani dan penerapan introduksi teknologi 1,28 dan 2,28. Nilai BEP Produksi dan BEP Harga untuk teknologi petani adalah Rp. 900/kg dan Rp. 6.714/kg, BEP (Break Event Point) Produksi dan BEP (Break Event Point) Harga untuk penerapan introduksi teknologi adalah 1.419 $\mathrm{Kg}$ dan $\mathrm{Rp} .6 .713,00$. Hasil penelitian ini dapat menjadi sumber informasi bagi pelaku usaha tani cabai dan pengambilan keputusan dalam penerapan introduksi teknologi dan budidaya cabai diluar musim yang berdampak terhadap peningkatan pendapatan petani.
\end{abstract}

Kata kunci: cabai merah; introduksi teknologi; lahan kering; BEP; R/C

\section{ABSTRACT}

Chili is one of the leading vegetable commodities that have a strategic role in national economic structure development. The price of chili in the market is quite unstable due to the low productivity of chili which can be caused by one of the factors such as the lack of chili cultivation technology application. This study aims to determine the effect of the technology introduction (the use of silver black mulch, border plants, and the use of spacing) given to farmers related to increasing the productivity of chili cultivation which has an impact on farmers' income. This study was conducted in Majene Regency, West Sulawesi Province on dry land agroecosystem with an adaptive research approach. Meanwhile, the data used are primary data and secondary data. The results of this study showed that chili cultivation with the technology introduction had a better impact, both in terms of production levels, suppressed pests, and disease attacks based on farmers' statements. The results of the feasibility analysis showed that the $B / C$ ratio and the $R / C$ ratio are based on how farmers and the technology introductions application are 1.28 and 2.28. While the value of BEP Production and BEP Price for farmer technology is IDR 900/kg and IDR 6,714/kg, Production BEP (Break-Even Point) and BEP (Break-Even Point). The price for the technology introduction application is IDR 1,419 $\mathrm{Kg}$ and IDR 6,713.00. The results of this study can be a source of information for chili farmers and decision making in the technology introduction application and chili cultivation outside the season which has an impact on increasing farmers' income.

Keywords: BEP; chili; dry land; R/C; technology introduction

\section{PENDAHULUAN}

Cabai merupakan salah satu komoditas yang memiliki potensi ekonomi untuk dibudidayakan secara luas baik didataran rendah maupun di dataran tinggi. Cabai merah termasuk salah satu komoditas sayuran yang memiliki peranan strategis dalam struktur pembangunan perekonomian nasional. Cabai merah memiliki peluang pasar yang cukup baik karena dapat dijual pada saat buah masih muda atau berwarna hijau dan pada saat buah telah tua atau berwarna merah. Buah cabai dapat dijual dalam bentuk kering, tepung dan bentuk olahan lainnya seperti sambal, oleaserin, bumbu, dan yang dihasilkan oleh industri (Litbang Pertanian, 2015).

Provinsi Sulawesi Barat di Tahun 2019 berdasarkan data Statistik Provinsi Sulawesi Barat diperoleh produksi cabai sebanyak 2.198 t dengan luas panen 480 ha. Produksi cabai tersebut tersebar di enam Kabupaten dengan produksi dan luas panen yang berbeda-beda. Produksi cabai berdasarkan luas kabupaten dapat dilihat 
pada Gambar 1 (Hafid, 2019). Produktivitas cabai dapat pula dilakukan dengan memanfaatkan lahan tegalan, ladang dan lahan yang tidak diusahakan dengan luas lahan masing - masing 134.821 ha, 52.279 ha dan 60.555 ha menjadi lahan produktif (BPS, 2019).

Budidaya tanaman cabai yang dilakukan di luar musim (kondisi curah hujan dan kelembaban yang tinggi) atau waktu off-season memiliki resiko dan kendala dari sisi budidaya. Kendala tersebut dapat berupa serangan OPT (Organisme Pengganggu Tanaman) yang dapat berdampak terhadap produktivitas tanaman yang rendah bahkan dapat berakibat gagal panen. Budidaya tanaman cabai diluar musim memberikan nilai ekonomi yang cukup tinggi karena ketersediaan yang cukup terbatas. Harga cabai yang dihasilkan diluar musim dapat mencapai Rp $35.000,00 / \mathrm{kg}$ ditingkat petani. Keberhasilan budidaya cabai diluar musim ditentukan oleh teknik budidaya khususnya dalam pengendalian hama dan penyakit tanaman, pemilihan varietas, pengolahan lahan yang tepat dan pemupukan tanaman yang efisien (Puslitbanghorti, 2020).

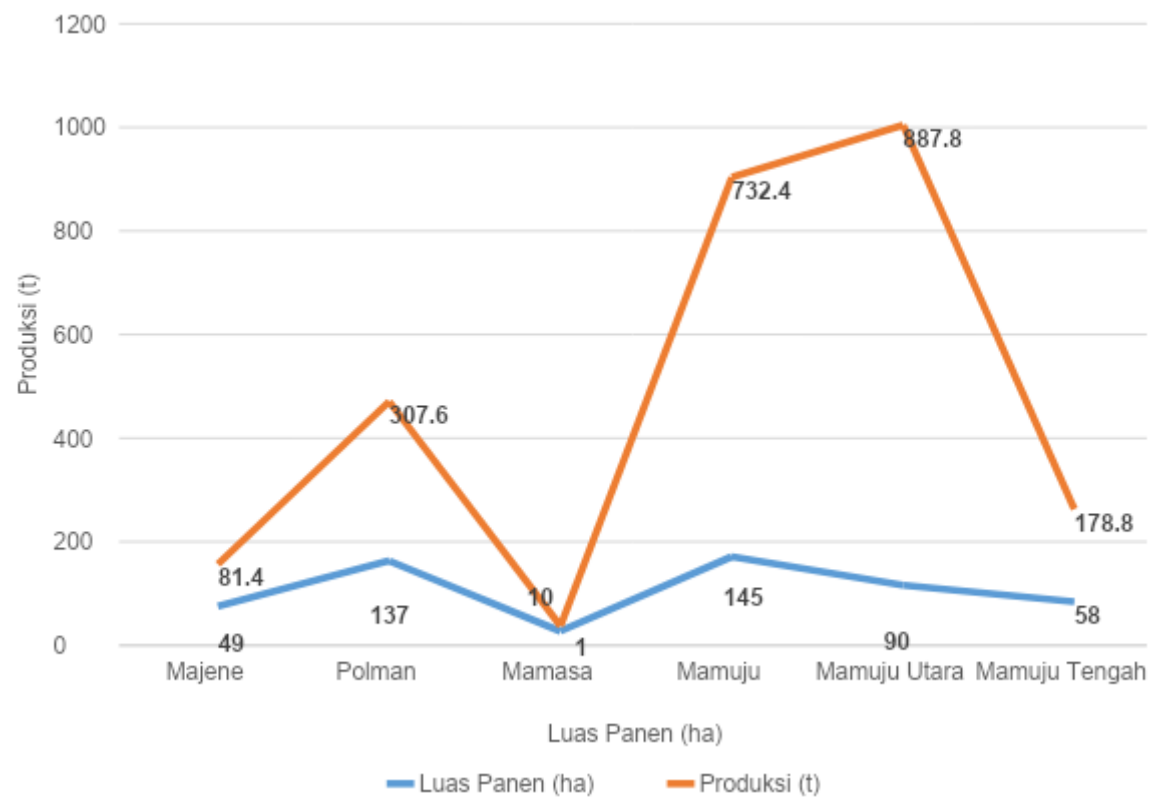

Gambar 1. Data luas panen dan produksi cabai di Provinsi Sulawesi Barat

Peningkatan produktivitas hasil budidaya tanaman cabai dapat dilakukan dengan melakukan penerapan teknologi budidaya yang tepat. Salah satu komponen dalam penerapan teknologi budidaya tanaman adalah penggunaan mulsa hitam perak, pengaturan jarak tanam, dan penggunaan tanaman pembatas yang dapat mengurangi tingkat serangan hama dan penyakit tanaman. Penggunaan mulsa pada tanaman dapat menjaga kelembaban tanah, suhu tanah dan kehilangan hara, melindungi tanah dari erosi, menekan pertumbuhan gulma sehingga mengurangi persaingan penyerapan unsur hara antara tanaman dan gulma, meningkatkan produksi tanaman atau jumlah buah pada tanaman dan berat pada buah segar (Novriani, 2018; Susiawan, 2018).

Penggunaan jarak tanam dalam teknik budidaya tanaman mengambil peran penting dalam pertumbuhan tanaman dan dapat mengurangi tingkat serangan hama dan penyakit tanaman pada saat musim hujan. Penggunaan jarak tanam yang lebih lebar akan mengurangi persaingan antara tanaman dalam memperoleh unsur hara dan air dari dalam tanah, serta penyerapan sinar matahari untuk proses fotosintesis sehingga pertumbuhan tanaman menjadi lebih optimal (Mahmudi, dkk., 2017). Hasil penelitian tersebut sejalan dengan penelitian Herawati (2014), pada komoditi kacang tanah bahwa penggunaan jarak tanam $30 \times 15 \mathrm{~cm}$ memberikan hasil yang efisien dengan $\mathrm{R} / \mathrm{C}$ ratio $=1,93$.

Penggunaan border pada pertanaman dapat menurunkan kejadian dan intensitas penyakit sebesar 15,3\% dan 16,98\% (Hidayah, dkk. 2015). Sebagaimana yang dilakukan oleh Soertiso, dkk., (2010) bahwa pada penggunaan tanaman ganda pada lokasi pertanaman mampu menekan jumlah serangga (trips) penyebab busuk batang dan jaringan daun sebanyak $62,50 \%$, kutu kebul, kutu daun dan serangan lalat buah. Tanaman yang dapat digunakan sebagai border tanaman atau tanaman perangkap adalah tanaman jagung dan bunga matahari (Lisdayani, dkk., 2017).

Pengaruh penggunaan komponen teknologi tersebut memberikan dampak terhadap peningkatan produktivitas buah cabai. Terjadinya peningkatan produktivitas tersebut memberikan dampak terhadap pendapatan petani cabai. Produktivitas yang rendah tersebut dipengaruhi oleh keterbatasan teknologi budidaya yang diterapkan oleh petani. Sementara teknologi budidaya cabai telah banyak dihasilkan oleh instansi penelitian dan perguruan tinggi yang dapat mendukung peningkatan produktivitas tersebut (Sudding, 2017). Selain itu, upaya peningkatan produktivitas tanaman dapat pula dilakukan efisiensi produksi, dimana petani dapat menggunakan input produksi yang sesuai dengan ketentuan untuk mendapatkan produksi yang optimal (Dewi, dkk., 2012).

Sistem budidaya tanaman cabai di Kabupaten Majene Provinsi Sulawesi Barat masih melakukan sistem budidaya tanaman cabai dengan menggunakan input teknologi yang cukup terbatas. Peningkatan produktivitas tersebut dapat dilakukan dengan menggunakan beberapa teknologi yang dapat mendukung peningkatan produktivitas cabai di Kabupaten Majene. Rata-rata Produksi buah cabai di Provinsi Sulawesi Barat pada Tahun 2019 adalah 4.579 t/ha dan Kabupaten Majene menyumbang produksi buah cabai dengan rata-rata produksi $1.661 \mathrm{t} / \mathrm{ha}$. Penelitian ini dilakukan dengan tujuan untuk mengetahui tingkat pendapatan petani cabai melalui introduksi teknologi mulsa hitam perak, penggunaan jarak tanam dan penggunaan tanaman perangkap dari jagung. 


\section{METODOLOGI}

\section{Tempat Pelaksanaan.}

Pelaksanaan kegiatan penelitian dilaksanakan di Kecamatan Banggae Timur, Kabupaten Majene Provinsi Sulawesi Barat. Lahan yang digunakan adalah agroekosistem lahan kering atau tadah hujan dengan pendekatan secara adaptif.

\section{Introduksi Teknologi.}

Introduksi teknologi yang dilakukan adalah, penggunaan Mulsa Hitam Perak (MHP), Penggunaan jagung sebagai tanaman border atau tanaman pembatas, dan penggunaan jarak tanam $(50 \mathrm{~cm} \times 60 \mathrm{~cm})$. Varietas yang digunakan adalah varietas Pilar yang umum digunakan oleh petani.

\section{Pengumpulan Data}

Data yang digunakan adalah data primer dan sekunder. Pengumpulan data sekunder melalui studi literatur, sedangkan data primer adalah data terkait dengan perkembangan lapangan meliputi produksi petani, biaya usahatani yang digunakan, penerimaan usahatani serta preferensi petani terkait dengan teknologi yang diintroduksikan. Selanjutnya dari data tersebut dilakukan analisa terkait dengan pendapatan petani dan kelayakan usaha budidaya dengan introduksi teknologi.

Analisis data yang digunakan untuk menentukan kelayakan usahatani dengan sistem teknologi introduksi yang dibandingkan dengan sistem budidaya cabai dengan menggunakan teknologi petani (kebiasaan petani) adalah jumlah pendapatan petani, jumlah pendapatan bersih, BCR (Benefit cost ratio), RCR (Revenue cost ratio), BEP (Break Even Point) harga dan BEP (Break Even Point) produksi.

\section{HASIL DAN PEMBAHASAN}

Hasil penelitian analisis budidaya cabai merah di kabupaten Majene, yang dilakukan melalui pendekatan adaptif. Penelitian pendekatan adaptif tersebut dilakukan di wilayah dimana petani sebelumnya melakukan budidaya cabai berdasarkan kebiasaan petani (KP) yang disandingkan dengan budidaya cabai dengan melakukan introduksi teknologi (IT). Introduksi teknologi merupakan suatu teknik budidaya cabai dengan melakukan penambahan input untuk memperoleh output atau produksi yang maksimal.

\section{Biaya Tetap dan Tidak Tetap.}

Biaya tetap yang digunakan dalam pelaksanaan kegiatan budidaya cabai adalah Rp6.270.000,00 (Tabel 1). Biaya tersebut termasuk biaya peralatan yang digunakan dan pajak tahunan lahan tersebut. Akan tetapi biaya tidak tetap yang timbul pada kegiatan budidaya tanaman cabai berbeda antara budidaya cabai dengan introduksi teknologi dan budidaya cabai berdasarkan kebiasaan petani. Selisih biaya yang timbul antara kedua teknik budidaya tersebut Rp11.085.00. Besaran biaya tersebut dipengaruhi oleh adanya penambahan input pada kegiatan budidaya dengan introduksi teknologi (Tabel 2).

Tabel 1. Biaya tetap budidaya tanaman cabai di luar musim.

\begin{tabular}{clcrr}
\hline No & \multicolumn{1}{c}{ Keterangan } & Jumlah & Harga Satuan (Rp) & Total Harga (Rp) \\
\hline 1. & Pajak bumi bangunan (ha) & 1 & $50.000,00$ & $50.000,00$ \\
2. & Cangkul (buah) & 2 & $150.000,00$ & $300.000,00$ \\
3. & Sekop (buah) & 2 & $110.000,00$ & $220.000,00$ \\
4. & Sabit (buah) & 2 & $100.000,00$ & $200.000,00$ \\
5. & Handsprayer (buah) & 2 & $950.000,00$ & $1.900 .000,00$ \\
6. Selang air (roll) & 3 & $250.000,00$ & $750.000,00$ \\
7. & Bak air (buah) & 1 & $1.500 .000,00$ & $1.500 .000,00$ \\
8. Pompa air (unit) & 1 & $600.000,00$ & $600.000,00$ \\
9. & Bak semai (buah) & 50 & $15.000,00$ & $750.000,00$ \\
\hline \multicolumn{2}{r}{} & & & $6.270 .000,00$ \\
\hline
\end{tabular}

Budidaya tanaman cabai yang dilakukan pada luasan areal $1 \mathrm{Ha}$ atau masing-masing 0,5 Ha untuk introduksi teknologi dan kebiasaan petani. Produksi buah cabai yang dihasilkan berbeda antara kedua teknik budidaya tersebut. Produksi buah cabai pada budidaya cabai dengan sistem introduksi teknologi sebanyak $4.650 \mathrm{~kg}$ sedangkan teknologi petani menghasilkan $2.950 \mathrm{Kg}$. Total produksi yang dihasilkan dari perlakuan tersebut diperoleh selisih sebesar $1.700 \mathrm{~kg}$. Nilai jual buah cabai dipasaran lokal berkisar $\mathrm{Rp} 22.000,00$ bahkan dapat mencapai harga $\mathrm{Rp}$ $35.000,00$ Kisaran harga tersebut berada pada bulan November sampai Januari.

\section{Pendapatan Usahatani Cabai}

Hasil budidaya tanaman cabai dengan introduksi teknologi yang dilakukan secara adaptif memberikan dampak terhadap produksi yang dihasilkan. Selisih produksi tersebut dapat disebabkan oleh adanya penambahan input produksi berupa penambahan pupuk kandang dan pengapuran lahan pertanaman sebelum dilakukan budidaya tanaman. Selain itu penggunaan MHP, border tanaman dan pengaturan jarak tanam turut berkontribusi terhadap peningkatan produksi. Rata-rata bobot tanaman yang dihasilkan dengan penerapan MHP menurut Nurhafsah, dkk (2020) adalah 14,3 gram sedangkan tanpa penerapan MHP adalah $12,5 \mathrm{gram}$.

Perbedaan bobot dan produksi buah cabai tersebut dipengaruhi oleh pemberian pupuk kandang. Pemberian penambahan pupuk kandang meningkatkan ketersediaan unsur hara bagi tanaman. ketersediaan unsur hara tersebut berdampak terhadap pertumbuhan tanaman yang baik dengan hasil yang baik pula bagi tanaman. Hasil penelitian tersebut sejalan dengan penelitian yang dilakukan oleh Safei dkk., (2014) bahwa, pemberian dosis pupuk organik mampu menghasilkan jumlah buah yang lebih banyak dan ukuran buah yang lebih panjang. Berdasarkan informasi dari petani bahwa MHP pada sistem budidaya cabai mampu menekan perkembangan hama dan penyakit tanaman sedangkan pada tanaman cabai tidak menggunakan MHP terserang lalat buah, penyakit busuk buah, antraknosa dan virus kuning. 
Tabel 2. Biaya tidak tetap budidaya tanaman cabai di luar musim.

\begin{tabular}{|c|c|c|c|c|c|c|}
\hline \multirow[t]{2}{*}{ No } & \multirow[t]{2}{*}{ Keterangan } & \multicolumn{2}{|c|}{ Jumlah Bahan } & \multirow{2}{*}{$\begin{array}{l}\text { Harga Satuan } \\
\text { (Rp) }\end{array}$} & \multicolumn{2}{|c|}{$\begin{array}{c}\text { Total Harga Bahan } \\
(\mathrm{Rp})\end{array}$} \\
\hline & & IT & $\mathrm{KP}$ & & IT & $\mathrm{KP}$ \\
\hline (1) & $(2)$ & (3) & (4) & $(5)$ & $6=(3 \times 5)$ & $7=(4 \times 5)$ \\
\hline 1. & Pengolahan lahan & $1 \mathrm{Kali}$ & $1 \mathrm{Kali}$ & $1.500 .000,00$ & $1.500 .000,00$ & $1.500 .000,00$ \\
\hline 2. & Pembuatan bedengan & 1 Paket & 1 Paket & $960.000,00$ & $960.000,00$ & $960.000,00$ \\
\hline 3. & Pupuk kompos & $10.000 \mathrm{Kg}$ & $6.000 \mathrm{Kg}$ & $10.000,00$ & $10.000 .000,00$ & $6.000 .000,00$ \\
\hline 4. & Bibit jagung & $5 \mathrm{Kg}$ & - & $15.000,00$ & $75.000,00$ & - \\
\hline 5. & Mulsa hitam perak & 6 Roll & - & $950.000,00$ & $5.700 .000,00$ & - \\
\hline 6. & Kapur pertanian & 15 Zak & - & $20.000,00$ & $300.000,00$ & - \\
\hline 7. & Tali rafia & 2 Roll & 2 Roll & $25.000,00$ & $50.000,00$ & $50.000,00$ \\
\hline 8. & Furadan & $2 \mathrm{Kg}$ & $2 \mathrm{Kg}$ & $30.000,00$ & $60.000,00$ & $60.000,00$ \\
\hline 9. & Polybaq & 80 Pak & 80 Pak & $10.000,00$ & $800.000,00$ & $800.000,00$ \\
\hline 10. & Bibit Cabai & $3 \mathrm{Bks}$ & $3 \mathrm{BKS}$ & $125.000,00$ & $375.000,00$ & $375.000,00$ \\
\hline 11. & Pupuk SP-36 & 3 Zak & - & $100.000,00$ & $300.000,00$ & - \\
\hline 12. & Pupuk Urea & 2 Zak & 4 Zak & $95.000,00$ & $190.000,00$ & $380.000,00$ \\
\hline 13. & Pupuk Za & 3 Zak & - & $125.000,00$ & $375.000,00$ & - \\
\hline 14. & Pupuk KCL & 3 Zak & - & $450.000,00$ & $1.350 .000,00$ & - \\
\hline 15. & Pupuk NPK Ponzka & & 4 Zak & $125.000,00$ & & $500.000,00$ \\
\hline 16. & Insektisida & 10 Liter & 10 Liter & $150.000,00$ & $1.500 .000,00$ & $1.5000 .000,00$ \\
\hline 17. & Fungisida & $15 \mathrm{Kg}$ & $15 \mathrm{Kg}$ & $60.000,00$ & $900.000,00$ & $900.000,00$ \\
\hline 18. & Pupuk daun & $5 \mathrm{Kg}$ & $5 \mathrm{Kg}$ & $12.000,00$ & $60.000,00$ & $60.000,00$ \\
\hline & & a tidak t & & & $24.495 .000,00$ & $13.085 .000,00$ \\
\hline
\end{tabular}

Keterangan: IT = Introduksi Teknologi; KP = Kebiasaan Petani

Tabel 3. Jumlah produksi dan pendapatan petani hasil budidaya cabai di luar musim.

\begin{tabular}{clrr}
\hline No & \multicolumn{1}{c}{ Keterangan } & Tek. Introduksi & Tek. Petani \\
\hline 1. & Jumlah produksi (kg) & 4.650 & 2.950 \\
2. & Total nilai jual petani (harga jual, Rp. 22.000) & $102.300 .000,00$ & $64.000 .000,00$ \\
3. & Pendapatan bersih petani (Rp) & $71.085 .000,00$ & $45.095 .000,00$ \\
\hline
\end{tabular}

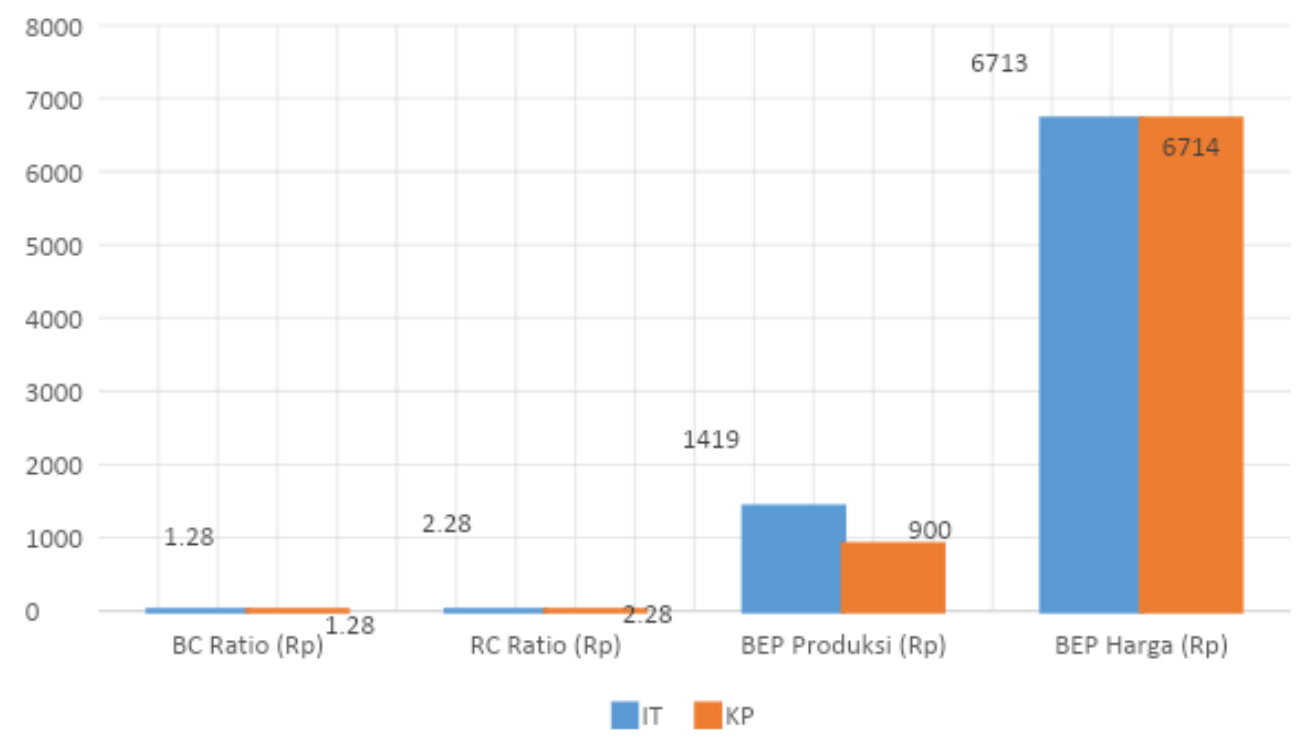

Gambar 2. Analisis kelayakan usaha tani cabai di luar musim

Jarak tanam yang terlalu rapat $(20 \mathrm{~cm} \times 30 \mathrm{~cm})$ menyebabkan serangan hama penyakit lebih tinggi, di musim penghujan sehingga kondisi lahan pertanaman yang cukup lembab, dan pertumbuhan gulma di areal pertanaman memicu serangan hama dan penyakit pada tanaman dibandingkan dengan jarak tanam $50 \mathrm{~cm} \times 60 \mathrm{~cm}$. Pendapatan bersih petani pada kegiatan budidaya cabai dengan penerapan introduksi teknologi lebih besar dibandingkan dengan teknologi petani. Selisih pendapatan bersih tersebut sebesar $\mathrm{Rp} 25.990 .000,00$ seperti yang terlihat pada Tabel 3.

Pendapatan bersih yang diperoleh oleh petani pada kegiatan tersebut dipengaruhi oleh penggunaan input teknologi. Produksi buah cabai pada penerapan introduksi teknologi memiliki produksi yang lebih tinggi dibandingkan dengan kebiasaan petani. Hal tersebut diduga bahwa budidaya tanaman cabai diluar musim memiliki tingkat serangan hama yang lebih tinggi karena curah hujan dan 
kelembaban yang tinggi. Rendahnya produksi yang dihasilkan pada budidaya cabai berdasarkan kebiasaan petani dapat pula disebabkan oleh jarak tanam yang digunakan dan kondisi cuaca yang sering hujan. Penelitian tersebut sejalan dengan penelitian (Sholiha, 2020), bahwa budidaya cabai dengan jarak tanam yang lebih rapat dan kondisi musim hujan menyebabkan panen tidak optimal. Pelaksanaan kegiatan budidaya tanaman cabai dengan introduksi teknologi dan kebiasaan petani layak untuk dilakukan karena $\mathrm{RC}$ ratio yang dihasilkan besar dari 1 (> 1). Artinya setiap pengeluaran biaya $\mathrm{Rp} 100$ akan memberikan pendapatan $\mathrm{Rp} 228,00$ dengan keuntungan yang diperoleh petani sebesar Rp 128,00. Semakin besar $\mathrm{RC}$ ratio maka makin besar pula penerimaan yang diperoleh oleh petani, sebagaimana yang dinyatakan oleh Ratnawati, dkk., (2019) bahwa besarnya keuntungan yang diterima oleh petani dalam pelaksanaan usahataninya dapat dilihat dari besarnya $\mathrm{RC}$ ratio yang dihasilkan. Begitupun keuntungan terhadap biaya yang diterima oleh petani dalam berusahatani yang dapat dilihat dari besarnya BC Ratio > 1. Hasil analisis BEP (Break Event Point) terhadap produksi dan harga pada usahatani yang dilakukan menunjukkan bahwa produksi yang dihasilkan lebih tinggi dari hasil analisis BEP produksi yang dihasilkan baik untuk teknologi introduksi maupun teknologi petani masing masing sebesar $32,31 \%$ dan $20,5 \%$. Nilai jual cabai merah yang dihasilkan memiliki nilai jual yang cukup tinggi dari hasil analisis BEP harga yang diperoleh. Selisih harga yang dihasilkan dari nilai jual yang diperoleh dengan nilai BEP harga yang dihasilkan merupakan nilai tambah produk yang dihasilkan. Nilai tambah produk yang dihasilkan dari teknologi introduksi sebesar Rp $15.287,00 / \mathrm{kg}$, sedangkan teknologi petani sebesar $\mathrm{Rp} 15.286,00 / \mathrm{kg}$. selisih nilai ekonomi untuk teknologi introduksi dan teknologi petani sebesar Rp1,00 Menurut Hendayana (2019) bahwa selisih harga antara harga aktual dengan harga impas mencerminkan nilai tambah ekonomi dari usahatani tersebut.

\section{KESIMPULAN}

Budidaya tanaman cabai dengan introduksi teknologi diperoleh pendapatan bersih yang lebih besar dibandingkan dengan kebiasaan petani, yaitu $R p$ 25.900.000,00. Budidaya tanaman cabai dengan introduksi teknologi dan kebiasaan petani layak untuk dilaksanakan dilihat nilai $R C$ ratio dan $\mathrm{BC}$ ratio besar dari 1. BEP harga teknologi introduksi dan teknologi petani memiliki nilai tambah produksi sebesar $32,31 \%$ dan $20,5 \%$ sedangkan nilai tambah ekonomi masing-masing sebesar Rp 15.287,00/kg dan $\mathrm{Rp} 15.286,00 / \mathrm{kg}$.

\section{UCAPAN TERIMA KASIH.}

Penelitian adaptif ini dilakukan dengan biaya DIPA BPTP Balitbangtan Sulawesi Barat. Ucapan terima kasih juga kami sampaikan kepada Ir. Cicu, M.Si dan Muhtar, SP atas bimbingan dan bantuannya selama penyelesaian tulisan ini.

\section{DAFTAR PUSTAKA}

Badan Litbang Pertanian. (2015). Petunjuk Teknis Budidaya Cabai di Luar Musim. Pusat Penelitian dan Pengembangan Hortikultura. Badan Penelitian dan Pengembangan Pertanian. Kementerian Pertanian. Jakarta.
BPS. (2019). Povinsi Sulawesi Barat dalam Angka "Sulawesi Barat Province in Figure" 2020. Badan Pusat Statistik Provinsi Sulawesi Barat.

Dewi I Gusti Ayu Chintya, I Ketut Suamba, I.G.A.A. Ambarawati. 2012. Analisis Efisiensi Usahatani Padi Sawah (Studi Kasus di Subak Pacung Babakan, Kecamatan Mengwi Kabupaten Bandung). Jurnal Agribisnis Dan Agrowisata Vol 1 (1): 1 - 10.

Hafid Abdul. (2019). Statistik Hortikultura Provinsi Sulawesi Barat 2019. BPS. Provinsi Sulawesi Barat. MamujuIndonesia.

Hendayana Rachmat. (2019). Analisis Data Pengkajian: Cerdas dan Cermat Menggunakan Alat Analisa Data untuk Karya Tulis IImiah. Cetakan ke-4. IAARD Press. Jakarta.

Herawati Nani, Sudarto, Baiq Tri Ratna Erawati. (2014). Kajian Variasi Jarak Tanam Terhadap Produktivitas Kacang Tanah di Lahan Kering. Prosiding Seminar Hasil Penelitian Tanaman Aneka Kacang dan Umbi. Hal: $679-686$.

Hidayah N, Sri S, dan Erlina A. (2015). Pengendalian Terpadu Penyakit Daun Keriting Kuning pada Cabai Merah. Skripsi Ilmu Hama dan Penyakit Tumbuhan. Fakultas Pertanian UGM.

Lisdayani, Marheni dan Darma B. (2017). Identifikasi Keanekaragaman Musuh Alami dengan Menggunakan Tanaman Perangkap. Jurnal Semdi Unaya. Hal 11 - 19.

Mahmudi, S., Hadi Rianto., dan Historiawati. (2017). Pengaruh Mulsa Hitam Perak dan Jarak Tanam pada Hasil Bawang Merah (Allium cepa fa.ascalonicum, L) Varietas Biru Lancor. Jurnal IImu Pertanian Tropika dan Subtropika No.2 (2): 60 - 62.

Nurhafsah, dkk. (2019). Pengaruh Penggunaan Mulsa Hitam Perak Terhadap Hasil Budidaya Cabai Merah Hibrida dan Non Hibrida di Sulawesi Barat. (Un Publish).

Puslitbanghorti. (2020). Teknologi Budidaya Off Season Cabai Merah. Pusat Perpustakaan dan Penyebaran Teknologi Pertanian. Kementerian Pertanian.

Ratnawati.I., Trisna. I.N., dan Lukman.H., (2019). Analisis Kelayakan Usahatani cabai Merah (Studi Kasus pada Kelompok Tani Mekar Subur Desa Maparah Kecamatan Panjalu Kabupaten Ciamis). J.llmiah Mahasiswa (Agroinfo Galuh) Volume 6 (2) : 422 429.

Sembiring Amri Putra. (2013). Pemanfaatan Mulsa Plastik Hitam Perak (MPHP) dalam Budidaya Cabai (Capsicum annum L). http://www.scribd.com. Di Akses, 23 Januari 2021; Jam 11.25 AM

Sholiha Siti M, Luluk Syahr Banu, Ani Nuraini, Petrus Amrih Piguno. (2020). Kajian Perbandingan Analisa Usaha Tani Produktivitas Tanaman Cabai Rawit di dalam Polibag dan di Lahan Pekarangan. Jurnal IImiah Respati Vol 11 (1): 13 - 23.

Soertiso, TA dan W.Setiawati. (2010). Kajian Teknis dan Ekonomis Sistem Tanam Dua Varietas Cabai Merah di Dataran Tinggi. Jurnal Horti No. 20 (3): 284 298.

Sudding Andi Faisal dan Yusmasari. (2017). Analisa Karasteristik Perilaku Usahatani Pertanian Cabai di Sulawesi Selatan. Buletin Inovasi Teknologi Pertanian No. $11: 43-50$.

Susiawan Yopp Sagita Hadi Rianto dan Yulia Eko Susilowati. (2018). Pengaruh Pemberian Mulsa Organik dan Saat Pemberian Pupuk NPK 15: $15: 15$ Terhadap Hasil Baby Buncis (Phaseolus vulgari L.) Varietas Perancis. J. IImu Pertanian Tropika dan Subtropika 3 (1); 22 - 24 
Novriani, Ekawati Daniah dan Rahmat Ariyadi. (2018). Pemanfaatan Limbah Pertanian sebagai Mulsa Organik untuk Mendukung Pertumbuhan dan Produksi Tanaman Bawang Daun (Allium fistulosum L.). J. Klorofil XIII (2): $78-82$. 